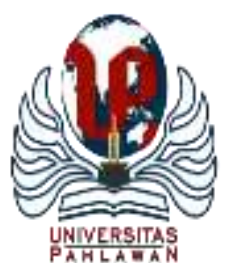

\title{
JURNALBASICEDU
}

Volume 6 Nomor 1 Tahun 2022 Halaman 1028 - 1036

Research \& Learning in Elementary Education

https://jbasic.org/index.php/basicedu

\section{Pengembangan LKPD Matematika Berbasis Model Inkuiri Terbimbing untuk Meningkatkan Berpikir Kritis Peserta Didik di Sekolah Dasar}

\section{Ira Damayanti ${ }^{1 凶,}$ Alben Ambarita ${ }^{2}$, Nurhanurawati ${ }^{3}$}

Program Studi Magister Keguruan Guru Sekolah Dasar, Pasca Sarjana Universitas Lampung ${ }^{1,2}$, Program Studi Magister Pendidikan Matematika, Pasca Sarjana Universitas Lampung ${ }^{3}$

E-mail: Ira.nekat@gmail.com ${ }^{1}$, alben@unila.ac.id ${ }^{2}, \underline{\text { nurhanurawati94@gmail.com }}^{3}$

\begin{abstract}
Abstrak
Tujuan dari penelitian ini adalah untuk mewujudkan produk LKPD yang valid dan efektif digunakan untuk meningkatkan kemampuan berpikir kritis siswa. Penelitian dilakukan di SDN 33 Negeri Katon. Penelitian ini merupakan Penelitian dan Pengembangan (R\&D) yang dilakukan dengan mengacu pada model desain Borg \& Gall. Hasil penelitian ini sesuai dengan hasil uji validitas pengembangan LKPD berbasis model pembelajaran inkuiri terbimbing dengan menggunakan ahli materi memperoleh skor 79, ahli media dengan skor 80,8, ahli linguistik dengan skor 87,5 dan LKPD berbasis model pembelajaran inkuiri terbimbing efektif digunakan dalam meningkatkan kemampuan berpikir kritis matematis. siswa pada nilai pretest dan posttest dengan hasil perhitungan N-Gain kelas eksperimen berada pada kategori efektif.
\end{abstract}

Kata kunci: Berpikir Kritis Matematika, Lembar Kegiatan Peserta Didik (LKPD), Model Pembelajaran inkuiri Terbimbing

\begin{abstract}
The objective of the study was to realize of valid and effective LKPD products used to improve students' critical thinking skills. The study was conducted at SDN 33 Negeri Katon. The study was a Research and Development $(R \& D)$ carried out by referring to the Borg \& Gall design model. The results of this study were in accordance with the results of the valid test of developing LKPD based on a guided inquiry learning model using material experts to achieve a score of 79, media expert with a score of 80.8, linguistics expert with a score of 87.5 and LKPD based on the guided inquiry learning model effectively used in improving mathematical critical thinking skills. students on the pretest and posttest scores with the results of the experimental class $N$-Gain calculation were in the effective category.

Keywords: Critical Thinking Mathematics, Student Activity Sheet (LKPD), Guided Inquiry Learning Model
\end{abstract}

Copyright (c) 2022 Ira Damayanti, Alben Ambarita, Nurhanurawati

Corresponding author :

Email : Ira.nekat@gmail.com

DOI : : https://doi.org/10.31004/basicedu.v6i1.2077 


\section{PENDAHULUAN}

Pendidikan di Indonesia saat ini belum optimal dalam menerapkan soal-soal yang memerlukan proses berpikir tingkat tinggi. Hal ini, bisa dilihat pada prestasi Indonesia di kancah dunia saat pertama mengikuti Program for International Students Asessment tahun 2003, Indonesia menduduki peringkat terbawah dari 40 negara peserta. Peringkat itu tidak jauh berubah pada 2006, 2009, 2012, 2015 dan terakhir 2018. Pada umumnya soal-soal yang digunakan pada PISA merupakan pertanyaan yang memerlukan daya berpikir yang lebih tinggi. Oleh karena itu, agar mampu bersaing dengan peserta didik dari negara lain dalam ajang PISA harus membekali diri dengan kompetensi yang mumpuni dari berbagai elemen ( Bialik, M., \& Fadel, C. 2015: $5)$.

Menurut (Azizah, dkk, 2018: 61) matematika diperlukan untuk membekali peserta didik menjadi pelajar yang mandiri dan mampu mengatasi permasalahan yang muncul dalam kehidupan. Oleh karena itu, pelaksanaan pembelajaran matematika tidak cukup hanya memberikan informasi berupa teori atau konsep yang bersifat hafalan saja, akan tetapi perlu adanya pengembangan keterampilan-keterampilan yang dibutuhkan dalam pemecahan masalah. Pada pembelajaran matematika, peserta didik perlu dilatih keterampilan berpikir kritis. (Hidaya,dkk 2017: 127) penelitiannya menyebutkan bahwa peserta didik tidak bisa mengerti pelajaran sejarah, biologi, ilmu sosial, atau matematika jika mereka tidak membaca dengan kritis. Pembelajaran hendaknya ditekankan pada keterampilan berpikir kritis agar peserta didik dapat mempraktikkan dan menstransfer pemahamannya.

Keterampilan berpikir kritis adalah proses kognitif peserta didik dalam menganalisis secara sistematis dan spesifik masalah yang dihadapi, membedakan masalah tersebut secara cermat dan teliti, serta mengidentifikasi dan mengkaji informasi guna merencanakan strategi pemecahan masalah. Pendapat tersebut diperkuat oleh (Rahmawati I, 2016: 1112) berpikir kritis adalah berpikir yang reflektif secara mendalam dalam pengambilan keputusan dan pemecahan masalah untuk menganalisis situasi, mengevaluasi argumen, dan menarik kesimpulan yang tepat.

Berdasarkan penjelasan di atas, keterampilan berpikir kritis merupakan salah satu kemampuan yang dapat digunakan dalam memecahkan masalah. Keterampilan berpikir kritis peserta didik Indonesia masih rendah. Hal tersebut dibuktikan pada hasil Trends in International Mathematics and Science Study (TIMSS) tahun 2015 menunjukkan bahwa skor matematika peserta didik Indonesia berada pada peringkat 44 dari 49 negara (Abdurrohman \& Djuniadi, 2016: 90).

Peserta didik yang memiliki kemampuan berpikir kritis yang baik dalam pembelajaran, rasa ingin tahunya tinggi dan menemukan sesuatu yang belum pernah dipelajarinya (Jabar. A, 2018: 1). Untuk mengungkapkan rasa ingin tahunya tersebut, peserta didik dituntut mampu mengomunikasikan dengan sesama teman sejawat ataupun pendidiknya. Kemampuan berpikir kritis peserta didik bisa dioptimalkan jika dibiasakan dan menjadi rutinitas dengan menyertakan contoh yang dekat dengan konteks keseharian mereka, sehingga mudah dimengerti. Selain itu pembelajaran akan lebih bermakna jika pendidik dan peserta didik terlibat aktif. Pendidik dalam melakukan pembelajaran matematika di kelas hendaknya memfasilitasi peserta didik dalam mengembangkan proses berpikir kritis (Nuryanti, L., Siti, Z., \& Markus, D. 2018: 155). Pendidik harus melakukan tindakan yang mendorong peserta didik merefleksikan kemampuannya. Oleh sebab itu pembelajaran matematika di sekolah sangat diperlukan kemampuan berpikir kritis peserta didik dari aspek mengidentifikasi, menghubungkan, mengevaluasi, menganalisis, dan memecahkan masalah berbagai persoalan matematika dan aplikasinya. Selain itu pendidik dituntut harus lebih kreatif dalam menggunakan metode, modelatau strategi pembelajaran yang merangsang peserta didik untuk aktif. Pembelajaran yang aktif diharapkan mampu merangsang kreativitas peserta didik, untuk menemukan ide, memecahkan masalah serta menarik kesimpulan dari masalah yang dihadapinya (Damayanti \& Mawardi, 2018). 
1030 Pengembangan LKPD Matematika Berbasis Model Inkuiri Terbimbing untuk Meningkatkan Berpikir Kritis Peserta Didik di Sekolah Dasar - Ira Damayanti, Alben Ambarita, Nurhanurawati

DOI: https://doi.org/10.31004/basicedu.v6i1.2077

Berdasarkan hasil studi pendahuluan yang dilakukan di kelas IV SD N 33 Negeri Katon, nilai rata-rata ulangan harian kelas IV SD N 33 Negeri Katon.

Tabel 1. Nilai Rata-rata Matematika Kelas IV

\begin{tabular}{clcc}
\hline No & Mata pelajaran & KKM & Nilai Rata-rata \\
\hline 1 & Bahasa Indonesia & 75 & 76 \\
\hline 2 & PPKn & 70 & 70 \\
\hline 3 & Matematika & 60 & 55 \\
\hline 4 & IPA & 70 & 70 \\
\hline 5 & IPS & 70 & 65 \\
\hline
\end{tabular}

Berdasarkan Tabel 1 diatas bahwa perolehan nilai rata-rata matapelajaran matematika di kelas IV SD N 33 Negeri Katon termasuk dalam kategori rendah karena masih di bawah KKM.

Selain itu peneliti melakukan wawancara terhadap pendidik, Hasil wawancara didapat informasi bahwa perolehan nilai rata-rata kelas mata pelajaran matematika di bawah KKM disebabkan banyak faktor, yaitu peserta didik yang cenderung tidak fokus saat belajar dan tidak memahami soal yang dianggapnya rumit, peserta didik malas untuk bertanya kepada pendidik, malas membaca buku paket dari sekolah, mengalami kesulitan memecahkan masalah dengan berpikir kritis, pendidik kurang maksimal dalam melatih peserta didik berpikir kritis, peserta didik lebih suka mendengar penjelasan dari pendidik sehingga pembelajaran terkesan monoton.

Salah satu faktor yang menentukan keberhasilan pengembangan kemampuan berpikir kritis peserta didik adalah ketepatan dalam memilih model pembelajaran yang tepat. Menurut (Sudjana, 2019: 63) di dalam proses pembelajaran, guru hendaknya memilih dan menggunakan pendekatan, model, strategi dan teknik yang dapat melibatkan siswa aktif dalam belajar, baik secara mental, fisik, maupun sosial. Hasil tersebut menunjukkan bahwa diperlukan suatu perbaikan pembelajaran untuk mencapai hasil kemampuan berpikir kritis serta hasil belajar yang lebih baik. Cara yang bisa dilakukan, yaitu pembelajaran yang selama ini diterapkan, pendidik harus diperbaharui guna meningkatkan kemampuan komunikasi matematika peserta didik menjadi lebih baik. Solusi untuk mengatasi hal tersebut diperlukan sebuah model pembelajaran yang aktif, inovatif bisa mendorong peserta didik untuk menemukan sesuatu yang belum pernah dipelajarinya. Sehingga pada penelitian ini akan mengacu pada model pembelajaran inkuiri terbimbing (guided inquiry).

Menurut (Dewi et.al, 2013: 1) guided inquiry merupakan model pembelajaran yang membantu peserta didik untuk belajar, dan memperoleh pengetahuan dengan cara menemukan sendiri apa yang sedang mereka pelajari. Sejalan dengan (Widyani \& Desak, 2018: 49) model pembelajaran guided Inquiry menekankan pada proses penemuan sebuah konsep sehinggamuncul sikap ilmiah pada diri peserta didik dan dapat dirancang penggunaannya oleh pendidik menurut tingkat perkembangan intelektual peserta didik. Sehingga model pembelajaran inkuiri terbimbing cocok diterapkan dalam meningkatkan kemampuan berpikir kritis peserta didik yang akan diteliti. Peserta didik akan belajar dengan keterampilan yang dimiliki kemudian menemukan sesuatu yang belum dipelajarinya sehingga rasa ingin tahunya tinggi.

Berdasarkan uraian dan masalah yang telah peneliti paparkan, untuk merangsang kemampuan berpikir kritis peserta didik yang rendah maka perlu dikembangkan LKPD matematika berbasis inkuiri terbimbing yang dikaitkan dengan benda riil dan penemuan konsep belajar matematis (Sriwongchai, 2015).

\section{METODE PENELITIAN}

Penelitian dan pengembangan atau Research and Development $(R \& D)$ adalah metode yang digunakan dalam penelitian ini. Prosedur pengembangan berdasarkan model ( Borg \& Gall, 1983: 775) melalui beberapa tahapan diantaranya : 1) Penelitian pendahuluan dan pengumpulan Informasi, 2) perencanaan, 3) 
1031 Pengembangan LKPD Matematika Berbasis Model Inkuiri Terbimbing untuk Meningkatkan Berpikir Kritis Peserta Didik di Sekolah Dasar - Ira Damayanti, Alben Ambarita, Nurhanurawati

DOI: https://doi.org/10.31004/basicedu.v6i1.2077

pengembangan bentuk produk awal, 4) Uji coba lapangan awal, 5) revisi produk awal, dan 6) uji lapangan untuk produk utama, 7). Penyempurnaan produk uji. Pelaksanaan studi pendahuluan dan uji coba perangkat LKPD dilakukan di IV SDN 33 Negeri Katon, sedangkan proses pengembangan LKPD dilakukan di kampus Universitas Lampung. Subyek penelitian adalah LKPD berbasis inkuiri terbimbing, sedangkan subyek uji coba produk adalah peserta didik kelas IV SD. Populasi dalam penelitian ini adalah peserta didik kelas IV SDN 33 Negeri Katon Pesawaran Lampung.

Pada penelitian ini, teknik pengambilan sampel yang digunakan adalah teknik purpose sampling. Sampel penelitian adalah peserta didik kelas kelas IV SDN 33 Negeri Katon yang menggunakan LKPD berbasis inkuiri terbimbing sebanyak 30 peserta didik. Teknik pengumpulan data pada penelitian pengembangan ini adalah sebagai menggunakan teknik nontes dan teknik tes. (Santosa, A.M., Sisworo., \& Dwiyana. 2018: 1511) Efektivitas penggunaan LKPD dilihat dari hasil belajar peserta didik yang sekaligus untuk mengukur kemampuan pemecahan masalah peserta didik. Data tersebut berupa data kuantitatif yang diperoleh melalui pre-test dan post-test (Tohir, 2015).

\section{HASIL DAN PEMBAHASAN}

Pada penelitian ini bertujuan untuk menghasilkan LKPD berbasis inkuiri terbimbing yang valid, praktis serta efektif untuk pembelajaran matematika kelas V Sekolah Dasar. LKPD yang dikembangkan, dinyatakan valid berdasarkan penilaian para ahli materi, ahli media, dan ahli bahasa. Selanjutnya setelah mengembangan produk awal maka peneliti meminta masukan dan saran dari para ahli sesuai bidangnya yaitu ahli materi, ahli media dan ahli bahasa. Uji ahli berfungsi untuk menilai kesesuaian bahan ajar yang dikembangkan dengan kebutuhan pembelajaran. Validasi ini diperoleh dari pengisian angket oleh validator. Hasil dari penilaian validator sebagai berikut.

a. Validasi materi/isi dilakukan oleh ahli yang kompeten terhadap bahan ajar, materi pada LKPD matematika berbasis inkuiri terbimbing dan strategi pembelajaran yaitu validator materi. Validasi dilakukan dengan cara pemberian angket sehingga dapat diketahui tingkat kevalidan nya. Hasil validasi terdapat pada tabel 2 Validasi Materi berikut ini.

Tabel 2 Skor Validasi Ahli Materi

\begin{tabular}{|c|c|c|c|}
\hline No & Aspek Penilaian & Jumlah Skor & Skor Maksimal \\
\hline 1 & Isi & 19 & 24 \\
\hline 2 & Sajian & 16 & 20 \\
\hline & Jumlah Skor & 35 & 44 \\
\hline & Nilai (\%) & \multicolumn{2}{|c|}{$79 \%$} \\
\hline & Kategori & \multicolumn{2}{|c|}{ Valid } \\
\hline
\end{tabular}

Berdasarkan Tabel.2 dapat dilihat hasil validasi ahli materi berbasis inkuiri terbimbing LKPD memperoleh persentase $79 \%$ dengan katagori valid/layak. Validator menyatakan bahwa produk LKPD berbasis Model Inkuiri Terbimbing yang dikembangkan layak diujicobakan untuk meningkatkan kemampuan berfikir kritis pada pembelajaran matematika kelas IV materi keliling persegi dan segitiga. Validator memberikan masukan agar instrumen soal-soal disesuaikan dengan masalah yang berkaitan dengan kehidupan peserta didik serta materi pembelajaran yang disesuaikan dengan indikator pencapaian kompetensi.

b. Validasi media dilakukan oleh ahli yang kompeten terhadap tampilan desain dan gambar dalam tampilan LKPD yaitu validator media. Validasi media diperlukan untuk menilai kemenarikan bahan ajar yang dikembangkan dari aspek media, dilakukan dengan cara pemberian angket sehingga dapat diketahui 
1032 Pengembangan LKPD Matematika Berbasis Model Inkuiri Terbimbing untuk Meningkatkan Berpikir Kritis Peserta Didik di Sekolah Dasar - Ira Damayanti, Alben Ambarita, Nurhanurawati DOI: https://doi.org/10.31004/basicedu.v6i1.2077

kelemahan dan kekuatannya, hasilnya dapat dilihat pada tabel 3.

Tabel 3 Skor Validasi Ahli Media

\begin{tabular}{lccc}
\hline No & Aspek Penilaian & Jumlah Skor & Skor Maksimal \\
\hline 1 & Keserdehanaan & 14 & 16 \\
\hline 2 & Keterpaduan & 6 & 8 \\
\hline 3 & Keseimbangan & 6 & 8 \\
\hline 4 & Bentuk & 10 & 12 \\
\hline 5 & Warna & 6 & 8 \\
\hline \multicolumn{3}{c}{ Nilai $\mathbf{\%})$} & $\mathbf{8 0 , 8 \%}$ \\
\hline & Kategori & Valid \\
\hline
\end{tabular}

Berdasarkan Tabel.3 dapat dilihat hasil validasi ahli media berbasis inkuiri terbimbing LKPD memperoleh persentase 80,8\% dengan katagori valid/layak. Validator memberikan masukan agar LKPD yang dikembangkan dibuat lebih kontekstual sesuai dengan lingkungan peserta didik. Selain itu, cover juga diberi gambar ke arah materi pembelajaran. Validator menyatakan bahwa produk penelitian berupa LKPD berbasis model inkuiri terbimbing layak digunakan untuk meningkatkan kemampuan berfikir kritis peserta didik kelas IV materi keliling persegi dan segitiga.

c. Validasi bahasa dilakukan oleh ahli yang kompeten terhadap tata tulis dan pengejaan EYD menurut kaedah kebahasaan dalam tampilan LKPD yaitu validator bahasa. Validasi bahasa diperlukan untuk menilai kelayakan bahan ajar yang dikembangkan dari aspek kebahasaan.

Tabel 4 Validasi Ahli Bahasa

\begin{tabular}{llcc}
\hline No & \multicolumn{1}{c}{ Aspek Penilaian } & Jumlah Skor & Skor Maksimal \\
\hline 1 & Keterbacaan & 3 & $\mathbf{4}$ \\
\hline 2 & Kejelasan informasi & 4 & 4 \\
\hline 3 & $\begin{array}{l}\text { Relevansi dengan kaidah Bahasa } \\
\text { Indonesia }\end{array}$ & 4 & $\mathbf{4}$ \\
\hline 4 & $\begin{array}{l}\text { Penggunaan bahasa secara efektif dan } \\
\text { efisien }\end{array}$ & 3 & 4 \\
\hline \multicolumn{2}{c}{ Jumlah } & 14 & 16 \\
\hline Nilai (\%) & \multicolumn{2}{c}{$\mathbf{8 7 , 5 \%}$} \\
\hline Kategori & \multicolumn{2}{c}{ Sangat Valid } \\
\hline
\end{tabular}

Berdasarkan Tabel.4 dapat dilihat hasil validasi ahli bahasa berbasis inkuiri terbimbing LKPD memperoleh persentase $87,5 \%$ dengan katagori valid/layak. Validator menyatakan produk pengembangan LKPD berbasis model inkuiri terbimbing layak untuk gunakan untuk meningkatkan kemampuan berfikir kritis peserta didik kelas IV materi keliling persegi dan segitiga. Namun, ada beberapa saran perbaikan yang diberikan sebagai masukan agar produk penelitian yang dikembangkan lebih baik, yaitu perbaikan dari segi kalimat yang digunakan sesuai EYD serta kesalahan bahasa yang ada di LKPD.

Setelah itu masuk pada tahap uji coba lapangan utama untuk mengetahui keefektifan LKPD yang dikembangkan, yaitu dengan melihat hasil pretest dan posttest, kemudian melihat perbedaan antara kelas kontrol dan kelas eksperimen, serta ketercapaian peserta didik dalam kemampuan berpikir kritis peserta didik.

a. Uji Normalized gain ( $N$-Gain) adalah uji analisis data yang bertujuan untuk mengetahui efektivitas penggunaan LKPD berbasis model pembelajaran inkuiri terbimbing. Hasil analisis n-gain yang diperoleh berdasarkan hasil pretest-posttest yang dilakukan pada penelitian ini dapat dilihat pada Tabel 5. 
1033 Pengembangan LKPD Matematika Berbasis Model Inkuiri Terbimbing untuk Meningkatkan Berpikir Kritis Peserta Didik di Sekolah Dasar - Ira Damayanti, Alben Ambarita, Nurhanurawati DOI: https://doi.org/10.31004/basicedu.v6i1.2077

Tabel 5 Hasil Rata-rata $\mathrm{N}$-Gain pada Kelas Eksperimen dan Kontrol

\begin{tabular}{clc}
\hline No & \multicolumn{1}{c}{ Kelas } & $N$-Gain $(\%)$ \\
\hline 1 & Kelas IVA (Eksperimen) & 67,87 \\
\hline 2 & Kelas IVB (Kontrol) & 28,26 \\
\hline
\end{tabular}

Berdasarkan hasil perhitungan Uji $\mathrm{N}$-Gain Score tersebut, menunjukkan bahwa nilai rata-rata $\mathrm{N}$-Gain Score untuk kelas eksperimen (penggunaan LKPD berbasis model pembelajaran inkuiri terbimbing) adalah sebesar 67,87\%. Sementara untuk nilai rata-rata $N$-Gain Score untuk kelas Kontrol (Pembelajaran Konvensional) adalah sebesar 28,26\%. Maka dapat disimpulkan bahwa penggunaan LKPD berbasis model pembelajaran inkuiri terbimbing efektif untuk meningkatkan kemampuan berpikir kritis peserta didik pada materi keliling persegi dan segitiga.

b. Sebelum dilakukan pengujian hipotesis dilakukan uji prasyarat yaitu uji normalitas dan homogenitas. Hasil analisis uji normalitas data di atas dapat disimpulkan bahwa data berdistribusi normal karena nilai Sig $>0,05$. Perhitungan secara lengkap dapat dilihat pada tabel 6

Tabel 6 Hasil Perhitungan Normalitas

\begin{tabular}{|c|c|c|c|c|c|c|c|}
\hline \multicolumn{8}{|c|}{ Tests of Normality } \\
\hline & \multirow[b]{2}{*}{ Kelas } & \multicolumn{3}{|c|}{ Kolmogorov-Smirnov ${ }^{\mathrm{a}}$} & \multicolumn{3}{|c|}{ Shapiro-Wilk } \\
\hline & & Statistic & Df & Sig. & Statistic & $\mathrm{df}$ & Sig. \\
\hline \multirow{2}{*}{ N-Gain_Persen } & Eksperimen & .087 & 30 & $200^{*}$ & .980 & 30 & .835 \\
\hline & Kontrol & .129 & 30 & $.200^{*}$ & .968 & 30 & .490 \\
\hline
\end{tabular}

*. This is a lower bound of the true significance.

a. Lilliefors Significance Correction

Pengambilan Keputusan:

- Jika nilai Sig. >0,05 maka data berdistribusi normal.

- Jika nilai Sig. $<0,05$ maka data tidak berdistribusi normal.

Berdasarkan data hasil Uji Normalitas Shapiro-Wilk tersebut dapat di simpulkan bahwa data berdistribusi normal karena nilai Sig. kelas Eksperimen dan Kontrol > 0,05 yaitu nilai Sig. kelas Eksperimen sebesar 0,835 dan nilai Sig. kelas Kontrol sebesar 0,490.

Selanjutnya ketiga dilakukan uji homogenitas didapatkan hasil sebagai berikut:

Tabel 7 Hasil Perhitungan Homogenitas

\begin{tabular}{|c|c|c|c|c|c|}
\hline \multicolumn{6}{|c|}{ Test of Homogeneity of Variance } \\
\hline & & Levene & & & \\
\hline & & Statistic & df1 & $\mathrm{df} 2$ & Sig. \\
\hline \multirow{4}{*}{$\begin{array}{l}\text { Hasil } \\
\text { Belajar } \\
\text { Siswa }\end{array}$} & Based on Mean & 17.111 & 1 & 58 & .000 \\
\hline & Based on Median & 8.077 & 1 & 58 & .006 \\
\hline & $\begin{array}{l}\text { Based on Median and } \\
\text { with adjusted df }\end{array}$ & 8.077 & 1 & 36.504 & .007 \\
\hline & $\begin{array}{l}\text { Based on trimmed } \\
\text { mean }\end{array}$ & 17.572 & 1 & 58 & .000 \\
\hline
\end{tabular}

Pengambilan Keputusan:

- Jika nilai Sig. > 0,05 maka data homogen

- Jika nilai Sig. $<0,05$ maka data tidak homogen. 
1034 Pengembangan LKPD Matematika Berbasis Model Inkuiri Terbimbing untuk Meningkatkan Berpikir Kritis Peserta Didik di Sekolah Dasar - Ira Damayanti, Alben Ambarita, Nurhanurawati

DOI: https://doi.org/10.31004/basicedu.v6i1.2077

Berdasarkan data tabel uji homogenitas di atas di dapatkan bahwa Sig. pada Based on mean adalah $0<$ 0,05 sehingga dapat disimpulkan bahwa data tidak homogen. Sehingga pengambilan keputusan dapat di lihat pada tabel uji T-Test Independen.

c. Kemudian pengujian hipotesis dilakukan dengan menguji uji-t (Independent sample t-test) atau uji beda rata-rata terhadap hasil pretest dan posttest peserta didik.

Syarat Uji T-Test Independen:

1. Data berdistribusi normal

2. Varians data homogen (bukan syarat mutlak)

Berdasarkan data output Group Statistics diketahui nilai Mean N-Gain_Persen untuk kelas Eksperimen adalah $67,87 \%$. Sehingga berdasarkan kategori tafsiran efektivitas nilai N-Gain (\%), maka dapat disimpulkan bahwa penggunaan LKPD berbasis model pembelajaran inkuiri terbimbing efektif untuk meningkatkan kemampuan berpikir kritis peserta didik pada materi keliling persegi dan segitiga. Selanjutnya diketahui nilai Mean N-Gain persen untuk kelas kontrol adalah 28,26\% sehingga berdasarkan kategori tafsiran efektivitas nilai N-Gain (\%), maka dapat disimpulkan bahwa penggunaan pembelajaran konvensional tidak efektif untuk meningkatkan kemampuan berpikir kritis peserta didik pada materi keliling persegi dan segitiga.

Selanjutnya dilakukan uji t dilakukan untuk melihat perbedaan antara kelas kontrol dan kelas eksperimen. Berdasarkan tabel output Independent Samples Test, diketahui nilai Sig. pada Levene's Test for Equality of Variances adalah sebesar $0,003<0,05$, maka dapat disimpulkan bahwa varians data N-Gain $(\%)$ untuk kelas eksperimen dan kelas kontrol adalah tidak homogen. Dengan demikian maka Uji T Independent untuk N-Gain Score berpedoman pada nilai Sig yang terdapat pada tabel Equal variances not assumed.

Berdasarkan tabel output Independent Samples Test tersebut, diketahui nilai Sig. (2-tailed) adalah sebesar $0<0,05$, dengan demikian maka dapat disimpulkan bahwa ada perbedaaan efektivitas yang signifikan (nyata) antara penggunaan LKPD berbasis Model Pembelajaran Inkuiri dengan penggunaan pembelajaran konvensional dalam meningkatkan kemampuan berpikir kritis peserta didik pada materi keliling persegi dan segitiga.

d. Pada uji selanjutnya akan mengetahui ketercapaian peserta didik dalam kemampuan berpikir kritis yang dikaitkan dengan setiap indikator kemampuan berpikir kritis matematika peserta didik yang dapat dilihat pada Tabel 8.

Tabel 8 Hasil Kemampuan Berpikir Kritis Matematika Peserta Didik ditinjau dari setiap indikatornya.

\begin{tabular}{|c|c|c|c|c|c|c|c|}
\hline \multirow[b]{2}{*}{ Pembelajaran ke- } & \multicolumn{5}{|c|}{ Indikator yang dinilai } & \multirow[b]{2}{*}{ Nilai } & \multirow[b]{2}{*}{ Kategori } \\
\hline & I & II & III & IV & $\mathrm{V}$ & & \\
\hline 1 & 74 & 65 & 66 & 55 & 62 & 64,4 & Sedang \\
\hline 2 & 78 & 69 & 77 & 65 & 78 & 73,4 & Sedang \\
\hline 3 & 84 & 76 & 79 & 70 & 82 & 78,2 & Tinggi \\
\hline Rata-rata & 76.5 & 67.5 & 70.5 & 60.5 & 70 & & \\
\hline
\end{tabular}

Sumber : Data Primer yang diolah

Berdasarkan Tabel 8, menunjukkan bahwa kemampuan berpikir kritis matematika peserta didik pada 3 pembelajaran, didapatkan nilai rerata dari 30 peserta didik setiap indikator dari kemampuan berpikir kritis yaitu indikator I sebesar 76.5, indikator II sebesar 67,5, indikator III sebesar 70,5, indikator IV sebesar 60,5 dan indikator V sebesar 70. Hasil penilaian terendah setiap indikator terletak pada indikator ke IV (Menyusun penjelasan berdasarkan data yang relevan dan tidak relevan). Hal tersebut perlu ditindaklanjuti dengan 
1035 Pengembangan LKPD Matematika Berbasis Model Inkuiri Terbimbing untuk Meningkatkan Berpikir Kritis Peserta Didik di Sekolah Dasar - Ira Damayanti, Alben Ambarita, Nurhanurawati

DOI: https://doi.org/10.31004/basicedu.v6i1.2077

memberikan latihan dengan memperkuat pada indikator tersebut, sehingga peserta didik dapat maksimal dalam mencapai semua indikator pada kemampuan berpikir kritis.

\section{KESIMPULAN}

Berdasarkan hasil penelitian dan pengebangan yang telah dilaksanakan dengan judul "Pengembangan LKPD Matematika Berbasis Model Inkuiri Terbimbing Untuk Meningkatkan Berpikir Kritis Peserta Didik di Sekolah Dasar" dapat disimpulkan bahwa :

1. LKPD berbasis model pembelajaran inkuiri terbimbing valid digunakan untuk meningkatkan kemampuan berpikir kritis peserta didik. Hal ini sesuai dengan hasil uji kevalidan LKPD berbasis inkuiri terbimbing oleh ahli materi mencapai persentase $79 \%$, ahli media mencapai persentase $80,8 \%$, ahli bahasa mencapai persentase $87,5 \%$. Berdasarkan penilaian dari 3 ahli maka diperoleh rata-rata sebesar $82,43 \%$ dan berada pada kategori sangat valid dan dapat digunakan dengan revisi sesuai dengan saran validator ahli.

2. LKPD berbasis inkuiri terbimbing efektif digunakan untuk meningkatkan kemampuan berpikir kritis peserta didik. Hal ini dibuktikan dengan nilai Mean N-Gain_Persen untuk kelas Eksperimen adalah 67,8755\% sehingga berdasarkan kategori tafsiran efektivitas nilai N-Gain (\%), maka dapat disimpulkan bahwa penggunaan LKPD berbasis model pembelajaran inkuiri terbimbing cukup efektif untuk meningkatkan kemampuan berpikir kritis peserta didik pada materi keliling persegi dan segitiga. Selanjutnya diketahui nilai Mean N-Gain_Persen untuk kelas Kontrol adalah 28,2572\% sehingga berdasarkan kategori tafsiran efektivitas nilai N-Gain (\%), maka dapat disimpulkan bahwa penggunaan pembelajaran konvensional tidak efektif untuk meningkatkan kemampuan berpikir kritis peserta didik pada materi keliling persegi dan segitiga. sehingga dalam tahap ini mengalami perubahan pada hasil belajar peserta didik

\section{DAFTAR PUSTAKA}

Abdurrohman \& Djuniadi. 2016. Analisis Kemampuan Berpikir Kritis Matematis Melalui Station

Learning Berpendekatan Metaphorical Thinking. Unnes Journal Of Mathematics Education Research. 5(2), 90-97.

Azizah, M., Joko, S., Nyai, C. 2018. Analisis Keterampilan Berpikir Kritis Siswa Sekolah Dasar Pada

Pembelajaran Matematika Kurikulum 2013. Jurnal Penelitian Pendidikan. 35(1), 61-70.

Bialik, M., \& Fadel, C. (2015). Skills For The 21 St Century: What Should Students Learn? Skills

For The 21st Century: What Should Students Learn?, 5.

Brog, Walter R., Dan Gall, Meredith Damien. 1989. New York. Education Research.

Borg,W.R., Gall, M.D. 1983. Educational Research: An Introduction. New York: Longman.

Damayanti, R., \& Mawardi, M. (2018). Developing Of MITRA Learning Model Of Inkuiri Mathematical Problems In Elementary School. Jurnal Prima Edukasia, 6(1), 1-10. Https://Doi.Org/10.21831/Jpe.V6i1.17238

Depdiknas. (2016). Lampiran 1 Permendiknas Nomor 22 Tahun 2006 Tentang Standar Isi. Depdiknas.

Dewi. Et Al. 2013. Pengaruh Model Pembelajaran Inkuiri Terbimbing Terhadap Sikap Ilmiah Dan Hasil

Belajar IPA. Journal Program Pascasarjana Universitas Pendidikan Ganesha Jurusan Pendidikan Dasar. Vol. 3: $1-10$.

Hidayah, Ratna, Dkk. 2017. Critical Thinking Skill: Konsep Dan Indikator Peniaian. Jurnal Taman 
1036 Pengembangan LKPD Matematika Berbasis Model Inkuiri Terbimbing untuk Meningkatkan Berpikir Kritis Peserta Didik di Sekolah Dasar - Ira Damayanti, Alben Ambarita, Nurhanurawati DOI: https://doi.org/10.31004/basicedu.v6i1.2077

Cendikia. 1(2), 127-133.

Jabar, A. 2018. Pembelajaran Inkuiri Terbimbing Dalam Pembelajaran Matematika Untuk Meningkatkan Kemampuan Penalaran Matematis Siswa SMP. Jurnal Pendidikan Matematika, 4(1), 1-10.

Nuryanti, L., Siti, Z., \& Markus, D. 2018. Analisis Kemampuan Berpikir Kritis Siswa SMP. Teori,

Penelitian, Dan Pengembangan. 3(2), 155-158.

Prastowo, Andi. 2013. Panduan Kreatif Membuat Bahan Ajar Inovatif. Yogyakarta. Diva Press.

Rahmawati, I., Arif, H., \& Sri, R. 2016. Analisis Keterampilan Berpikir Kritis Siswa SMP Pada Materi

Gaya Dan Penerapannya.Pros. Semnas Pend. IPA Pascasarjana UM, (1), Hlm. 1112-1119.

Santosa, A.M., Sisworo., \& Dwiyana. 2018. Pembelajaran Matematika Dengan Menggunakan Metode

Penemuan Terbimbing Untuk Meningkatkan Kemampuan Penalaran Induktif Siswa Smp. Jurnal Pendidikan: Teori, Penelitian, Dan Pengembangan, 3(9), 1151-1159.

Sriwongchai, A. (2015). Developing The Mathematics Learning Management Model For Improving Creative Thinking In Thailand. International Education Studies, 8(11), 77. Https://Doi.Org/10.5539/Ies.V8n11p77

Sudjana, N., \& Ahmad, R. 2019. Media Pengajaran. Bandung: Sinar Baru.

Sugiyono.2011.Metode Penelitian Kuantitatif Kualitatif Dan R \& D. Bandung: Alfabeta.

Tohir, A. (2015). Pengembangan Bahan Ajar Modul Kesetimbangan Kimia Berbasis Multipel Representasi Di SMA Kota Bandar Lampung. Program Pascasarjana Teknologi Pendidikan Fakultas Keguruan Dan Ilmu Pendidikan Universitas Lampung.

Trianto. 2017. Mendesain Model Pembelajaran Inovatif-Progresif. Jakarta. Kencana.

Widyani, N.L.S., \& Desak, P.P. 2018. Peningkatan Sikap Ilmiah Matematika Melalui Penerapan Model Pembelajaran Inkuiri Terbimbing Di SD N Banjar Jawa. Journal Of Education Action Research. 2(1), 4957.

Zubaidah, Amir. MZ, Dkk. 2019. Pengaruh Penerapan Strategi Metakognitif Terhadap Kemampuan Pemecahan Masalah Matematis Bedasarkan Kemandirian Belajar Siswa. Anargya: Jurnal Ilmiah Pendidikan Matematika. 